Pediat. Res. 5: 2-9 (1971)

$\begin{array}{ll}\text { Fetus } & \text { infants } \\ \text { gamma globulin } & \text { maternal-fetal } \\ \text { Gm factor } & \text { incompatibility }\end{array}$

\title{
Gm Factor Fetomaternal Gamma Globulin Incompatibility
}

\author{
Gerald Nathenson [35], Julian B. Schorr, and Stephen D. Litwin \\ Department of Pediatrics, Montefiore Hospital and Medical Center and the Albert Einstein College of Medicine; Department of Pathology, \\ Albert Einstein College of Medicine; Department of Medicine (Genetics), Cornell Medical College and New York Hospital; \\ and New York Blood Center, New York, New York, USA
}

\begin{abstract}
Extract
Sera of 1763 normal pregnant women were screened for antibodies against $\mathrm{Gm}(\mathrm{a}), \mathrm{Gm}$ (b), and $\mathrm{Gm}$ (f) factors. Twenty-eight patients (1.59\%) possessed specific $\mathrm{Gm}$ agglutinators. Incidence of fetal death, synthesis of the incompatible genetic gamma globulin factor, and levels of gamma globulin were determined. Four infants with $\mathrm{Gm}$ factor fetomaternal incompatibilities whose mothers possessed isoantibodies were studied over a period of from 8 to 24 months. Serial quantitative gamma globulin determinations from the affected infants produced results which compared favorably with seven control infants and normal values cited in the literature. There appeared to be no impairment of synthesis of the specific incompatible genetic gamma globulin, expressed as a titer of hemagglutination inhibition. The development of specific genetic gamma globulin factors throughout infancy is delineated. In the patients studied, no adverse effects resulted from fetomaternal gamma globulin incompatibility.
\end{abstract}

\section{Speculation}

High titers of maternal $\mathrm{Gm}$ antibody of the gamma $\mathrm{G}$ fraction may traverse the placenta and result in suppression of synthesis of the corresponding gamma globulin of the infant. Low titers cannot reach the fetal circulation in sufficient quantities to produce suppression. Alternatively, despite high levels of maternal antibody, no biological effects may result.

\section{Introduction}

Genes at the $\mathrm{Gm}$ locus of the chromosome control the synthesis of gamma $\mathrm{G}$ globulin heavy chains. The $\mathrm{Gm}$ genes impart antigenic specificities, termed $\mathrm{Gm}$ factors. These genetic factors allow for the description of differences between people. The $\mathrm{Gm}$ antigen can induce the formation of specific antibodies in individuals who lack that factor. Antibodies to $\mathrm{Gm}$ factors are often present in patients who receive multiple blood transfusions [1]. They may appear during pregnancy in a mother who lacks a $\mathrm{Gm}$ factor present in the fetus [8] or in the baby who lacks a factor present in the mother $[25,27]$. Patients with rheumatoid arthritis often possess $\mathrm{Gm}$ antibodies [11]; normal individuals rarely do so [23]. Experimental isoimmunization to a specific allotype in pregnant animals can result in suppression of synthesis of that allotypically defined gamma globulin in the offspring [4, 12], or in a striking degree of fetal mortality [14]. This prospective study was undertaken to determine genetic gamma globulin synthesis, and to follow the general health and survival of the human infant under circumstances similar to that observed in the experimental animal. 


\section{Materials and Methods}

The presence of specific antibodies to $\mathrm{Gm}(\mathrm{a}), \mathrm{Gm}(\mathrm{b})$, and $\mathrm{Gm}(f)$ factors [29] was sought in a prenatal clinic population of white, Negro, and Puerto Rican women over a 2-year period. The technique of genetic identifcation of gamma globulins and antibodies is inhibition of the hemagglutination reaction in a system consisting of Rh-positive red blood cells coated with anti-Rh gamma globulin of a specific genetic type; a corresponding specific antibody; and $\mathrm{Gm}$-specific gamma globulin as an inhibitor [26]. Knowledge of two of the three components permits identification of the unknown third. Specimens of maternal prenatal sera screened for antibodies were obtained from the blood bank of a neighboring hospital [30].

Reagents used to determine $\mathrm{Gm}$ factors are detailed in Table I. The specificities of the $\mathrm{Gm}$ agglutinators listed were established in a previous study [15]. To establish the genetic specificities of the maternal antibodies of this study, each agglutinator was tested for hemagglutination-inhibition with a panel of inhibitors of known genetic type.

To identify $\mathrm{Gm}$ antibodies of the variety found in rheumatoid factors, maternal sera containing genetic agglutinators were tested by a modification of the latex fixation method [9]. A titer of 1:40 or greater was considered positive.

To determine whether a potential existed for fetomaternal $\mathrm{Gm}$ factor incompatibility, $\mathrm{Gm}$ typing of paternal serum was done in each of the families enrolled in the study.

When fetomaternal $\mathrm{Gm}$ incompatibility appeared, further characterization of maternal antibody into $19 \mathrm{~S}$ and $7 \mathrm{~S}$ components was carried out by determination of antibody titer before and after reduction with $1 \mathrm{M}$ 2-mercaptoethanol [22], and by separation through Sephadex G-200 gel in a $1.5-\mathrm{cm}$ by $90-\mathrm{cm}$ column [7] using $0.15 \mathrm{M}$ Tris buffer in $0.15 \mathrm{M} \mathrm{NaCl}$ at $\mathrm{pH} 8.0$. The serum specimens were first dialyzed against cold distilled water, and the macroglobulins were separated. Both fractions were then separately applied to the column. Concentration of the column effluent was achieved by ultrafiltration through a collodion membrane of pore size less than $5 \mathrm{~m}_{\mu}$ [13].

Eleven babies born to mothers with $\mathrm{Gm}$ antibodies were followed carefully through infancy to determine whether the genetic factor against which maternal antibody might react was present in the offspring. When present, the development of the genetic factor was sraced by serial measurements of titer capable of pro-
Table I. Reagents used to determine $\mathrm{Gm}$ factors

\begin{tabular}{cccllr}
\hline $\begin{array}{c}\text { Gm } \\
\text { factor }\end{array}$ & Agglutinator & $\begin{array}{c}\text { Recip- } \\
\text { rocal } \\
\text { of } \\
\text { dilution }\end{array}$ & Source & Anti-D & $\begin{array}{c}\text { Recip- } \\
\text { rocal } \\
\text { of } \\
\text { dilu- } \\
\text { tion }\end{array}$ \\
\hline (a) & VACC & 40 & Human & TRENT & 5 \\
& B6 & 600 & Baboon & TRENT & 5 \\
(b) & 881 & 400 & Rabbit & DeSTEPH & 5 \\
& 949 & 100 & Rabbit & 7171 & 10 \\
(f) & 876 & 100 & Rabbit & RIV & 5 \\
\hline
\end{tabular}

Table II. Prenatal screening

\begin{tabular}{lrrr}
\hline & & $\begin{array}{c}\text { Mothers, } \\
\%\end{array}$ & $\begin{array}{c}\text { Agglutina- } \\
\text { tors, } \\
\%\end{array}$ \\
\hline No. of mothers & 1763 & & \\
Mothers with agglutinators & 28 & 1.59 & \\
Gm(a) agglutinators & 21 & 1.20 & 75 \\
Gm(b) agglutinators & 5 & 0.28 & 18 \\
Gm(f) agglutinators & 2 & 0.11 & 7 \\
\hline
\end{tabular}

ducing hemagglutination-inhibition in the appropriate system.

Routine well baby care was provided by one of the authors (G.N.) to all but one of the infants enrolled in the study. Blood specimens for analyses were drawn during these visits.

Serial quantitative determinations of gamma globulins were performed by the technique of radial diffusion in commercially available plates $[18,31]$.

Antibody titers to live attenuated poliovirus vaccine were determined by tissue culture neutralization [24], and to attenuated measles vaccine by the hemagglutination-inhibition technique [6].

Informed consent was obtained from parents of all patients taken into the study.

\section{Results}

Sera of 1763 pregnant women were screened for antibodies against $\mathrm{Gm}$ (a), $\mathrm{Gm}$ (b), and $\mathrm{Gm}$ (f) factors. Twenty-eight mothers or $1.59 \%$ possessed antibodies, of which $75 \%$ were of the $\mathrm{Gm}(\mathrm{a}), 18 \% \mathrm{Gm}(\mathrm{b})$, and $7 \% \mathrm{Gm}(\mathrm{f})$ varieties (Table II).

Four hundred and seven repeated determinations were carried out on sera of 204 mothers during their pregnancies (an average of three different determinations done for each mother). None developed $\mathrm{Gm}$ antibodies during the pregnancy. All but 1 of the 28 mothers possessing specific antibodies delivered normal term infants. The one exception resulted in the birth 
Table III. Gm phenotypes of families with fetomaternal Gm incompatibilities

\begin{tabular}{lllll}
\hline & Mother & Father & Infant & Maternal antibody \\
\hline$C H \sigma^{\top}$ & $(\mathrm{a}+\mathrm{b}+\mathrm{f}-)$ & $(\mathrm{a}+\mathrm{b}+\mathrm{f}+)$ & $(\mathrm{a}+\mathrm{b}+\mathrm{f}+)$ & Anti-Gm(f) \\
$R F \&$ & $(\mathrm{a}-\mathrm{b}+\mathrm{f}+)$ & $(\mathrm{a}+\mathrm{b}+\mathrm{f}-)$ & $(\mathrm{a}+\mathrm{b}+\mathrm{f}+)$ & Anti-Gm(a) \\
$A M \sigma^{\pi}$ & $(\mathrm{a}+\mathrm{b}-\mathrm{f}-)$ & $(\mathrm{a}+\mathrm{b}+\mathrm{f}+)$ & $(\mathrm{a}+\mathrm{b}+\mathrm{f}+)$ & Anti-Gm(b) \\
$B D \&$ & $(\mathrm{a}-\mathrm{b}+\mathrm{f}+)$ & $(\mathrm{a}+\mathrm{b}+\mathrm{f}+)$ & $(\mathrm{a}+\mathrm{b}+\mathrm{f}+)$ & Anti-Gm(a) \\
\hline
\end{tabular}

Table IV. Antibody studies: mothers with fetomaternal $\mathrm{Gm}$ incompatibilities

\begin{tabular}{|c|c|c|c|c|c|c|c|c|}
\hline \multirow{2}{*}{ Infants } & \multirow{2}{*}{ Maternal antibody } & \multirow{2}{*}{ Titer } & \multirow{2}{*}{ Date } & \multicolumn{2}{|c|}{ 2-Mercaptoethanol } & \multicolumn{2}{|c|}{$\begin{array}{l}\text { Sephadex G-200 separation } \\
\text { antibody activity }\end{array}$} & \multirow{2}{*}{$\begin{array}{l}\text { Latex } \\
\text { fixation }\end{array}$} \\
\hline & & & & Titer before & Titer after & $19 \mathrm{~S}$ & $7 \mathrm{~S}$ & \\
\hline \multirow[t]{4}{*}{$C H$} & $\mathrm{Gm}(\mathrm{f})$ & $1: 32$ & Mar. '66² & $1: 8^{3}$ & Neat & + & \pm & Negative \\
\hline & & $1: 16$ & Aug. '66 & & & & & \\
\hline & & $1: 8$ & Feb. '67 & & & & & \\
\hline & & 0 & July '67 & & & & & \\
\hline \multirow[t]{4}{*}{$R F$} & $\mathrm{Gm}(\mathrm{a})$ & $1: 32$ & Jun. '66² & $1: 16$ & $1: 2$ & \pm & \pm & Negative \\
\hline & & $1: 16$ & Aug. ' $66^{2}$ & & & & & \\
\hline & & $1: 8$ & Jan. '67 & & & & & \\
\hline & & 0 & Oct. '67 & & & & & \\
\hline \multirow[t]{2}{*}{$A M$} & $\mathrm{Gm}(\mathrm{b})$ & $1: 64$ & Aug. '672 & $1: 64$ & $1: 64$ & 0 & + & Negative \\
\hline & & $1: 64$ & Oct. '67 & & & & & \\
\hline \multirow[t]{4}{*}{$B D$} & $\mathrm{Gm}(\mathrm{a})$ & $1: 16$ & Aug. ' 672 & $1: 16$ & $1: 4$ & + & + & Negative \\
\hline & & $1: 16$ & Jan. '68 & & & & & \\
\hline & & $1: 16$ & May '68 & & & & & \\
\hline & & $1: 32$ & Mar. '69 & & & & & \\
\hline
\end{tabular}

\pm notation indicates trace activity.

Prenatal specimens.

Specimen of Mar. ' 66 done at a later time.

of immature stillborn twins. Screening of the sera of 22 mothers of idiopathic stillborn infants failed to reveal agglutinators to the $\mathrm{Gm}$ factors tested. Maternal antibody titers ranged from $1: 2$ to $1: 64$. The latex fixation test was positive in 2 mothers of the 25 tested. No history of rheumatoid disease was elicited in either woman.

Eleven families were enrolled in the study. Four of 11 demonstrated fetomaternal $\mathrm{Gm}$ incompatibilities (Table III). The 7 remaining infants were compatible with their mothers.

The prenatal antibody specimens of the four incompatible mothers were treated with 2-mercaptoethanol. Three of the four sera showed a significant reduction in titer of two or more twofold serial dilutions, suggesting that a substantial proportion of the agglutinating activity was due to mercaptoethanol-sensitive 19S antibody, but that some activity might be due to $7 \mathrm{~S}$ antibody. No change in titer occurred in the serum of the mother of infant $A M$, suggesting the presence of only $7 \mathrm{~S}$ antibody. To provide further information on the molecular distribution of anti-Gm activity, the four sera were separated into $19 S$ and $7 S$ fractions by passage through Sephadex G-200 gel. The 7S fraction contained no gamma $M$ globulin when tested by immunodiffusion against a gamma $M$ antiserum. Localization of antibody activity to the $19 \mathrm{~S}$ or $7 \mathrm{~S}$ fractions, or both, was demonstrated (Table IV). Antibody activity was present in the cord serum of infant $A M$ to a titer of 1:8. All other cord sera lacked agglutination when tested for the possibility of maternal antibody.

The distribution of gamma $\mathrm{G}$ globulin concentrations in the compatible babies compared well with values of normal children reported by Allensmith et al. [2] using the same method (Fig. 1).

The gamma G globulin concentrations of the four incompatible infants are shown in Figure 2. The scatter of points of three of the four distribute well within \pm 2 SD of Allensmith's mean values. One of the four infants, between 6 and 10 months of age ( $\Delta)$, appeared to skirt the lowest limits of gamma $G$ globulin concentration, but later fell well within 2 SD of the mean.

Using the same reference source for the normal development of gamma $\mathrm{M}$ and gamma A globulins, both 
the Gm-compatible and -incompatible groups fall well within the normal limits.

Figures 3, 4, 5, 6, and 7 show the progressive development througl infancy of genetic factors contained on gamma $G$ globulins in those incompatible babies who possessed a $\mathrm{Gm}$ type absent in the mother. The amount of genetic factor present was expressed as the titer capable of inhibiting the hemagglutination reaction in the $\mathrm{Gm}$ system studied. The genetic factor was not present at birth since in effect only maternal gamma $\mathrm{G}$ globulin was measured.

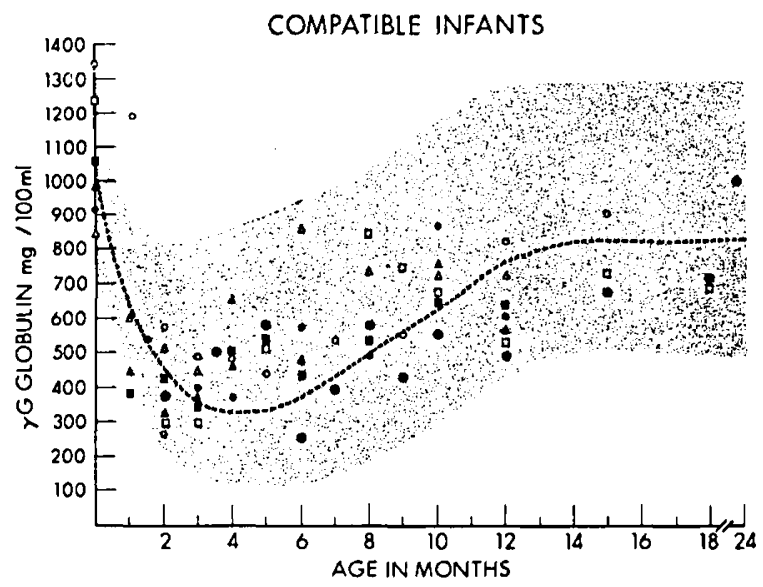

Fig. 1. Scattergram of gamma $\mathrm{G}$ globulin levels throughout infancy of seven babies with compatible fetomaternal $\mathrm{Gm}$ factors. Background represents geometric mean (dashed line) $\pm 2 \mathrm{sD}$ in normal children. Modified from Allensmith et al. [2]. Each of the seven symbols represents one patient.

\section{INCOMPATIBLE INFANTS}

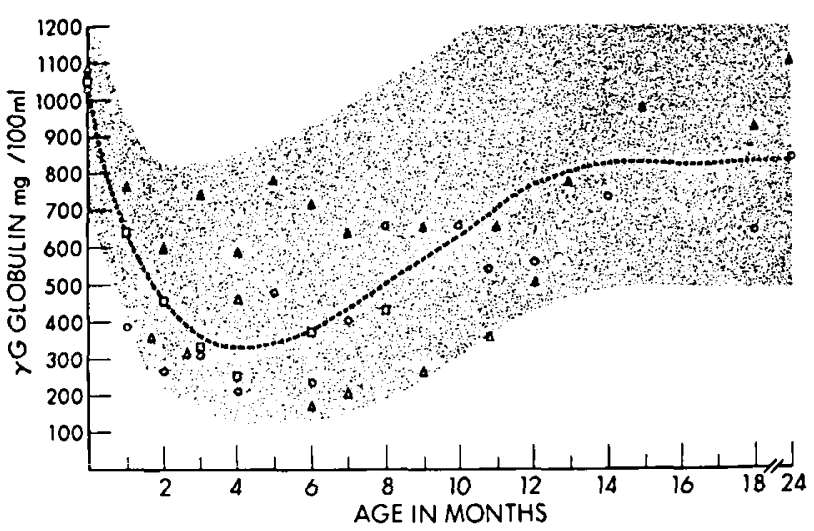

Fig. 2. Scattergram of gamma $G$ globulin levels throughout infancy in four babies with fetomaternal $\mathrm{Gm}$ incompatibility and maternal sensitization. Background represents geometric mean (dashed line) \pm 2 sD in normal children, modified from Allensmith et al. [2]. Each of the four symbols represents one patient.

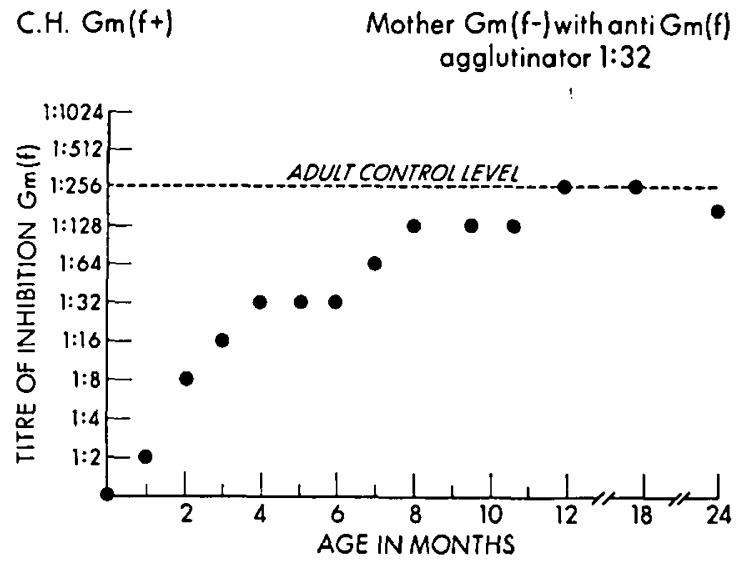

Fig. 3. The development of $\mathrm{Gm}$ (f) factor throughout infancy in patient $\mathrm{CH}$, whose mother possesses a $\mathrm{Gm}(\mathrm{f})$ antibody.

$$
\begin{gathered}
\text { Mother } G m(a-f \text { withanti } G m(a) \\
\text { agglutinator } 1: 32
\end{gathered}
$$

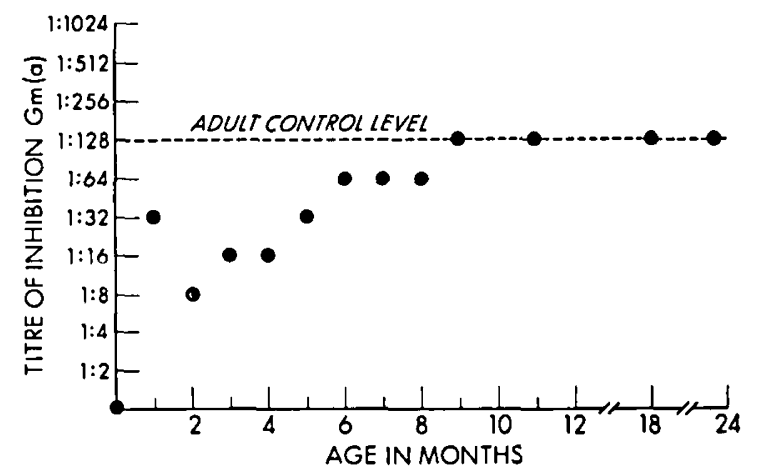

Fig. 4. The development of $\mathrm{Gm}$ (a) factor throughout infancy in patient $R F$, whose mother possesses a Gm (a) antibody.

\section{Patients}

$\mathrm{CH}$ (Fig. 3) was $\mathrm{Gm}(\mathrm{f}+$ ); his mother $\mathrm{Gm}(\mathrm{f}-$ ) with a $\mathrm{Gm}$ (f) agglutinator. The progressive rise of titer to levels of adult control sera reflected the endogenous production of gamma $G$ globulin carrying this $\mathrm{Gm}$ phenotype. To equate titer with a specific quantity of gamma $G$ globulin is not possible, but in general a rise in titer reflects increasing quantities of type-specific gamma $\mathrm{G}$ globulin.

$R F$ (Fig. 4) was $\mathrm{Gm}(\mathrm{a}+)$; her mother $\mathrm{Gm}(\mathrm{a}-$ ) with a Gm (a) antibody. Of note was the prompt rise in titer at 1 month of age, then a slight decrease and slow subsequent rise during infancy to adult control levels. At 3 weeks of age this patient was admitted to the hospital with a febrile illness. Throat culture revealed the presence of group $A \beta$-hemolytic streptococcus.

$B D$ (Fig. 5) was $\mathrm{Gm}(\mathrm{a}+)$; her mother $\mathrm{Gm}(\mathrm{a}-)$ with a $\mathrm{Gm}$ (a) agglutinator. A progressive rise of $\mathrm{Gm}$ (a) 


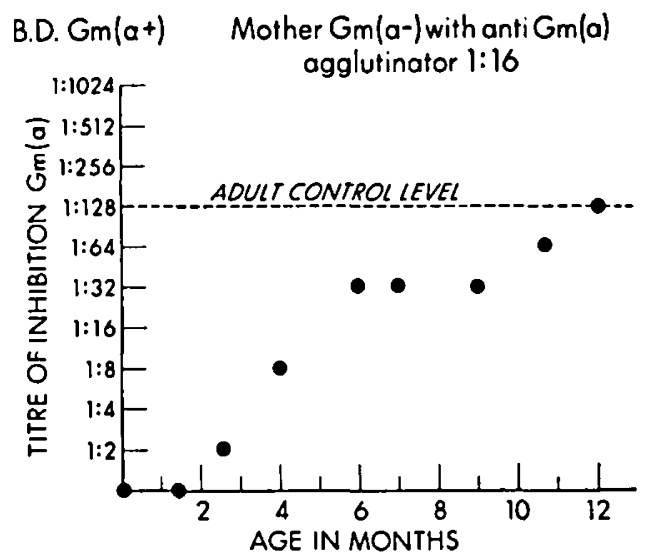

Fig. 5. The development of $\mathrm{Gm}$ (a) factor throughout infancy in patient $B D$, whose mother possesses a $\mathrm{Gm}$ (a) antibody.
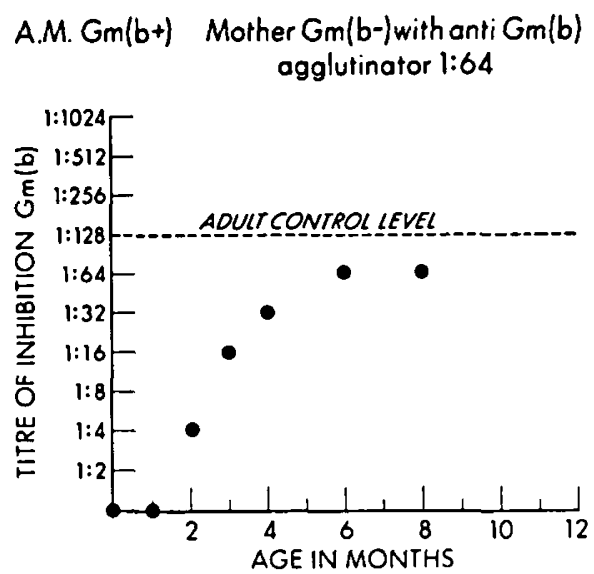

Fig. 6. The development of $\mathrm{Gm}$ (b) factor throughout infancy in patient $A M$, whose mother possesses a $\mathrm{Gm}$ (b) antibody.

factor can be seen despite the low levels of gamma G globulin which were noted in Fig. 2 between 6 and 10 months of age. A level of inhibition of hemagglutination comparable to the adult controls was attained by 1 year of age.

$A M$ (Fig. 6) was $\mathrm{Gm}(\mathrm{b}+)$; his mother $\mathrm{Gm}(\mathrm{b}-$ ) with a Gm (b) agglutinator. The development of the titer of inhibition is shown in the Gm (b) system. There was a smooth upward progression toward adult control levels up to 8 months of age. The patient was then lost to follow-up. $A M$ is once again presented as a control in the $\mathrm{Gm}$ (f) system (Fig. 7). His mother possessed no $\mathrm{Gm}$ (f) antibody. The progressive rise in titer resembled that seen in all preceding examples with maternal antibody.

The health of all four infants was excellent. Except for the $\beta$-hemolytic streptococcal infection in patient $R F$, none have had significant illness. Patient $R F$ has subsequently shown no undue susceptibility to infection. Satisfactory antibody responses to live attenuated polio virus vaccine and to attenuated measles vaccine were found in each of the four patients.

\section{Discussion}

Genes at the $\mathrm{Gm}$ locus control the synthesis of heavy chains of the gamma $\mathrm{G}$ molecules. Over $20 \mathrm{Gm}$ factors are now known, and 4 antigenically different gamma $G$ heavy chains have been identified [15]. The gamma Gl chain carries the $\mathrm{Gm}$ (a) and $\mathrm{Gm}(\mathfrak{f})$ markers and is the major class of heavy chains, comprising about $70 \%$ of normal gamma $G$ proteins. The gamma G2 chain carrying $\mathrm{Gm}(\mathrm{n})$ and the gamma G3 heavy chain with its $\mathrm{Gm}(\mathrm{b})$ and $\mathrm{Gm}(\mathrm{g})$ factors provide 18 and $8 \%$ of gamma $G$ molecules, respectively. The gamma G4 heavy chain has no known genetic marker and accounts for $3 \%$ of the total population of gamma G globulins [21]. Should selective suppression of heavy chain synthesis occur with anti-Gm factors, loss of the gamma Gl chain could produce an appreciable decrease in total gamma globulin levels. It is likewise possible that suppression of one member of an allelic pair could lead to compensatory overproduction of the opposite member with no decrease in gamma globulin levels.

The original method of genetic analysis of gamma globulins utilized agglutinators present in rheumatoid factors of some individuals producing this form of antibody [11]. Specific genetic agglutinators, however, can be found in normal populations and range in incidence from 0.2 to $6.6 \%[3,28]$. The lower figures characterize those seen in adult groups, and the higher

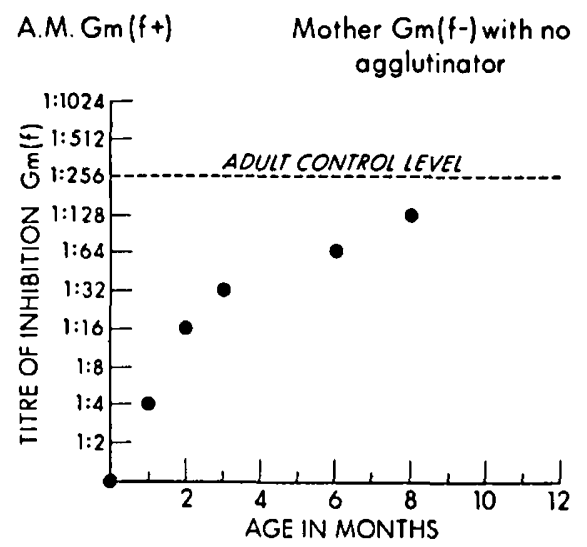

Fig. 7. The development of $\mathrm{Gm}$ (f) factor in patient $A M$, throughout infancy. There is no maternal antibody against $\mathrm{Gm}$ (f). 
percentages those seen in children. Genetic agglutinators found in normal individuals are largely of $19 \mathrm{~S}$ variety, but some $7 \mathrm{~S}$ antibody is produced and, when present during pregnancy, can sometimes be found in the fetal circulation $[19,20]$. Patients subjected to multiple blood transfusions often develop antibodies against specific genetic characters of gamma globulin. Injection of pooled human gamma globulin also serves as a stimulus to antiglobulin production [8]. In pregnant mothers, antibody production can be induced by the passage of fetal gamma globulin of a different genetic character across the placenta into the maternal circulation [8]. Likewise, the leak of maternal gamma globulin into the fetal circulation can be responsible for the induction of antibodies in the infant [25, 27]. The relation between rheumatoid factors and genetic agglutinators is not clearly understood.

Wilson and Steinberg [28], using six typing systems, found an antibody frequency of $0.9 \%$ in normal adults. The $1.59 \%$ incidence seen in the prenatal group studied is based on the three typing systems used. The somewhat higher incidence possibly reflects differences in the experimental conditions of this investigation. Of 204 pregnant women whose sera were repeatedly tested for agglutinators during pregnancy, none developed $\mathrm{Gm}$ antibodies. Thus, pregnancy did not appear to enhance the development of anti-Gm factors.

Experimental sensitization of female animals with species-specific gamma globulin of different genetic character results, as anticipated, in the elaboration of anti-gamma globulins to the protein administered. Allotypically heterozygous rabbit offspring of homozygous parents, where the mother possesses an antibody to the father's genetic type, show striking depression of the inherited paternal allele $[4,5,17]$. This depression persists for a prolonged period of time [16]. Compensatory overproduction of the maternal allele accompanies the depression of its mate; hence, total gamma globulin levels are not depressed.

A striking number of maternal and fetal deaths occur in certain strains of pregnant mice with induced antibodies to paternal allotypes [14]. Similar experiments with still other strains of mice result in depression of gamma globulin synthesis without compensatory overproduction of an unaffected allotype and without fetal or maternal death [12].

The striking effects produced experimentally in animals and the capacity for humans to develop isoimmunization to genetic gamma globulin factors prompted prospective observations of infants born to mothers possessing $\mathrm{Gm}$ agglutinators. Antibodies to $\mathrm{Gm}(\mathrm{a}), \mathrm{Gm}(\mathrm{b})$, and $\mathrm{Gm}(\mathrm{f})$ factors were sought. These genetic factors were chosen because of the availability of specific agglutinators as reagents, permitting the development of typing systems in our laboratory, and because of the possibility of detecting an appreciable decrease in quantitative gamma G globulin levels, should $\mathrm{Gm}$ (a) and $\mathrm{Gm}$ (f) molecules be suppressed.

Production of specific genetic gamma globulins of the gamma $G$ class was delineated, and general well being and survival were documented. The only deaths occurred to one Gm-sensitized mother, who delivered immature stillborn twins. It is not known whether these offspring were incompatible with the mother. A search for antibodies in the sera of 22 mothers who delivered idiopathic stillborn infants failed to reveal sensitization to the $\mathrm{Gm}$ factors studied.

The quantitative gamma $G$ globulin levels of the incompatible infants and of the controls distributed well within the limits set by Allensmith $e t$ al. for normal children. Although gamma G globulins of one infant $(B D)$ transiently fell to the lowest limits of normal over a 4-month period, levels did not fall below these limits and thus this patient cannot be regarded as truly hypogammaglobulinemic.

The development of specific genetic factors in the incompatible patients expressed as the titerable capacity of the infant's serum to inhibit hemagglutination is traced throughout infancy. Patient $A M$ served as both a subject (in the $\mathrm{Gm}$ (b) system) and as a control ( $\mathrm{Gm}$ (f)). The developmental rates of $\mathrm{Gm}(\mathrm{f})$ in patient $\mathrm{CH}$, $\mathrm{Gm}(\mathrm{a})$ in patient $B D$, and $\mathrm{Gm}(\mathrm{b})$ in patient $A M$ were similar to that described for patient $A M$ in the $\mathrm{Gm}(\mathrm{f})$ system where no maternal antibody existed. This strongly suggests that no suppression of gamma G globulin production occurred in those infants whose mothers possessed antibodies. Since titer does not reflect a specific known quantity of gamma globulin, however, the question of suppression of an allele and compensatory overproduction of its mate, resulting in normal gamma globulin levels, cannot be completely ruled out.

One exception to the similarity of curves appeared in the progression of the Gm (a) factor of patient $R F$. A striking increase in titer was seen at 1 month of age following a $\beta$-hemolytic streptococcal infection; then a decline and subsequent rise, as seen in the other subjects. One might speculate that the early rapid rise in genetic factor titer reflected this patient's response to the stimulus of the streptococcal infection. 
It would then appear that fetomaternal $\mathrm{Gm}$ factor gamma globulin incompatibility with maternal sensitization resulted in no clearly defined deficiencies of gamma globulin synthesis in those patients studied, and in no alteration of survival. An explanation for the differences in outcome observed in the animal experiments and in the human can possibly be found in the mode of transmission of antibodies in utero from mother to fetus in mice and rabbits as compared with man. In the rodent and lagomorph, maternal antibodies transfer to the fetus by absorption from yolk sac and to the newborn by way of the colostrum [10]. This permits all classes of gamma globulins to gain access to the fetal and neonatal circulation. Since only gamma $G$ globulin crosses the human placenta and only small amounts of anti-Gm factors are found in this class of globulins, probably too little $\mathrm{Gm}$ antibody reaches the fetal circulation. Antibody activity in low titer was found in the cord serum of patient $A M$, whose mother possessed a $\mathrm{Gm}$ antibody of $7 \mathrm{~S}$ character. No antibody was identified in the cord sera of the other patients. Possibly small quantities of antibody can be neutralized by small amounts of endogenously produced fetal $\mathrm{Gm}$ factor, as suggested by Mårtensson and Fudenberg [20].

\section{References and Notes}

1. Allen, J. C., ANd Kunkel, H.: Antibodies to genetic types of gamma globulin after multiple transfusion. Science, 139: 418 (1963).

2. Allensmith, M., McClellan, B. H., Butteriworth, M., AND Maloney, J. R.: The development of immunoglobulin levels in man. J. Pediat., 72: 276 (1968).

3. Audran, R.: Fréquence des sérums anti-Gm et anti-D nécessaires à la détermination des groups sériques Gm. C.R. Acad. Sci., 259: 4183 (1964).

4. Dray, S.: Effect of maternal isoantibodies on the quantitative expressions of 2 allelic genes controlling gamma globulin allotypic specification. Nature, 195: 677 (1962).

5. Dubiski, S.: Suppression of synthesis of allotypically defined immunoglobulins and compensation by another subclass of immunoglobulin. Nature, 214: 1365 (1967).

6. ENDERs, J. F.: Hemagglutination by microtitre technique. In: E. H. Linette: Diagnostic Procedures for Viral and Rickettsial Diseascs, Ed. 3, p. 549. (American Public Health Association, New York, 1964).

7. Flodin, P.: Fractionation of peptides and proteins. In: Dextran Gels and Their Applications in Gel Filtration, Chapt. 8. (Pharmacia, Uppsala, 1962).

8. FUdenberg, H., AND Fudenberg, B. R.: Antibody to hereditary gamma globulin $(\mathrm{Gm})$ factor resulting from matcrnal-fetal incompatibility. Science, 145: 170 (1964).

9. Goldin, M., AND Black, A.: Evaluation of a new preserved latex antigen for the serodiagnosis of rheumatoid arthritis. Ann. Rhcum. Dis., 23: 485 (1964).

10. Good, R. A., ANd Pafermaster, B. W.: Ontogeny and phylogeny of adaptive immunity. Advan. Immunol., 4: 1 (1965).

11. GRUBB, R.: Hereditary gamma globulin groups in man. Amer. J. Hum. Genet., 13: 171 (1961).

12. Herzenberc, L. A., Goodlin, R. C., and Ribera, E. C.: Immunoglobulin synthesis in micc. J. Exp. Med., 126: 701 (1967).

13. Кават, E. A., ANo Meyers, M. M.: Experimental Immunochemistry, Ed. 2, Chapt. 43. (Thomas, Springficld, Ill., 1964).

14. Lieberman, R., AND DRAY, S.: Maternal-fetal mortality in mice with isoantibodies to paternal gamma globulin allotypes. Proc. Soc. Exp. Biol. Ned., 16: 1069 (1964).

15. Litwin, S. D., AND Kunkel, H. G.: The genetic control of gamma globulin heavy chains. J. Exp. Med., 125: 847 (1967).

16. Mage, R., and Dray, S.: Persistent altered phenotypic expression of allelic gamma G-immunoglobulin allotypes in heterozygous rabbits exposed to isoantibodies in fetal and neonatal life. J. Immunol., 95: 525 (1965).

17. Mage, R., Young, G. O., and Dray, S.: An effect upon the regulation of genc expression. J. Immunol., 98: 502 (1967).

18. Mancini, G., Carbonara, A. O., and Heremans, J. F.: Immunochemical quantitation of antigens by single radial im. munodiffusion. Immunochemistry, 2: 235 (1965).

19. MIÁRTENsson, L.: Anti $\mathrm{Gm}$ molecules with distinctly different physio-chemical properties. Acta Pathol. Microbiol. Scand., 56: 353 (1962).

20. MRktensson, L., ANd FudenberG, H.: Gm genes and gamma globulin synthesis in the human fetus. J. Immunol., 97: 514 (1965).

21. Natvig, J. B., Kunkel, H. G., And Gedde-Dahl, T.: Genetic studics of the heavy chain subgroups of gamma $G$ globulin. In: J. Killander: Nobel Symposium 3, Gamma Globulins, p. 313. (Interscience, New York, 1967).

22. Petz, L. D., and Fudenberg, H. H.: Coombs-positive hemolytic anemia caused by penicillin administration. New Engl. J. Med., 274: 171 (1966).

23. Ropartz, C., Lenoir, J., Hemet, Y., and Rivat, L.: Possible origins of the anti-Gm sera. Nature, 188: 1120 (1960).

24. Sснмid, $\mathbf{N}$. J.: Neutralizing antibody assay in African Green Monkey kidncy monolayer cell cultures. In: E. H. Linctte: Diagnostic Procedures for Viral and Rickettsial Diseases, Ed. 3, p. 120. (American Public Health Association, New York, 1964).

25. Sreiser, P.: Uber antikorperbildung von sauglingen und kleinkindern gergen mutterliches gamma 2 globulin. Wien. Med. Wochenschr., 113: 966 (1963).

26. Steinberg, A. G.: Progress in the study of genetically determined human gamma globulin types (the Gm and Inv groups). Progr. Med. Genet., 2: 1 (1962).

27. Steinberg, A. G., AND Wilson, J. A.: Hereditary globulin factors and immune tolerance in man. Science, 140: 303 (1963).

28. Wilson, J., AND Steinberg, A.: Antibodies to gamma globulin in the serum of children and adults. Transfusion, 5: 516 (1965).

29. World Health Organization terminology: $G m(a)=G m(1)$, $\mathrm{Gm}(\mathrm{b})=\mathrm{Gm}(5), \mathrm{Gm}(\mathrm{f})=\mathrm{Gm}(4)$.

30. Bronx Municipal Hospital Center, New York, N. Y.

31. Immunoplates, Hyland Laboratories, Oxnard, Calif. 
32. The capable technical assistance of Barbara Zaleski is gratefully acknowledged. The authors also thank I. Spigland, M.D., for viral antibody determinations; Miss M. S. Ballard for technical assistance; and Mrs. J. White for preparation of the manuscript.

33. Supported by Public Health Service Research Grant no. HD 02737 .
34. Presented in part at the 39th Annual Meeting of the Society for Pediatric Research, Atlantic City, N. J., May 3, 1969.

35. Requests for reprints should be addressed to: Gerald Nathenson, M.D., Department of Pediatrics, Montefiore-Morrisania Affiliation, 168th St. and Gerard Ave., Bronx, N. Y. 10452 (USA).

36. Accepted for publication March 16, 1970. 